\title{
Why Adding Duties to European Citizenship Is Likely to Increase the Gap Between Europhiles and Eurosceptics
}

\author{
Theresa Kuhn
}

Citizenship is not only a legal device to determine who is member of a political community and hence has both civic rights and duties. It has also always been a tool to integrate its members and strengthen a sense of collective identity and political legitimacy. With this integrative power in mind, Maurizio Ferrera proposes to add both a social dimension and some duties to European citizenship that should strengthen the social bonds across the EU. His proposals are innovative and intriguing, and have triggered a wide array of very insightful reactions in this forum debate. Rather than reacting to each of these policy proposals, I will focus on the proposed duties as they most closely relate to my research interests. I will then make two alternative proposals that target the stayers and try to mitigate the gap between winners and losers of European integration.

In short, Ferrera suggests to add both civic and financial duties to European citizenship. This makes a lot of sense as people often fail to appreciate the goods and services they get for free and start caring for a common good once they have to contribute to it. Let me explain why I nonetheless doubt that these duties will have the effect that Ferrera is hoping for. Rather than strengthening a sense of European identity across the board, these duties risk widening the gulf between pro-European citizens and those opposing European integration. We are currently witnessing the emergence of an increasingly important fault line in European politics between highly educated, mobile Europhiles, and lower skilled, immobile Eurosceptics who see themselves as (and sometimes are) the losers of European integration. ${ }^{1}$ Let me discuss how the duties proposed by Ferrera have different implications for Europhiles and Eurosceptics and hence have unintended consequences for European collective identity.

1 Hooghe, L. \& G. Marks (2017), 'Cleavage theory meets Europe's crises:

Lipset, Rokkan, and the transnational cleavage', Journal of European Public Policy 25 (1): 109-135; Kuhn, T. (2015), Experiencing European integration. Transnational lives and European identity. Oxford: Oxford University Press. 
Ferrera proposes to introduce the possibility of paying a voluntary, earmarked contribution to 'Social Europe' on national tax forms. The rationale behind this proposal is that such a contribution could make the EU more salient and visible, and by paying into such a fund, citizens could be 'nudged' into caring and feeling responsible for the European Union. Similar mechanisms have been thought to contribute to nation building, and experiments in behavioural economics indeed support the expectation that individuals become more caring once they contribute to a common good. One has to ask, however, who will be the European citizens that are ready to pay a voluntary contribution to 'social Europe'. Very likely, this is the group of Europeans that is already convinced of the benefits of European integration. Recent studies on redistribution across the European Union show that citizens with cosmopolitan values are most willing to share resources with other Europeans, and they are most likely to support international redistribution in the EU. ${ }^{2}$ Eurosceptics, however, most probably refrain from paying such a contribution, and will therefore also fail to develop the sense of responsibility and ownership through their contribution that Ferrera is hoping for.

Ferrera further suggests introducing an EU civilian defence and civic community service, again with the hope that taking part in such a service will instil some sense of community. In fact, such initiatives exist already. Over the past 20 years, 100,000 young people aged 17-30 have participated in the European Voluntary Service. ${ }^{3}$ Moreover, the newly created European Solidarity Corps provides a unique platform for young Europeans and organisations that wish to get involved in projects related to European solidarity. These are great initiatives, but will Eurosceptic youth be willing to participate? While I am not aware of any studies on the European Voluntary Studies, research on Erasmus exchange programmes is informative. While an Erasmus experience has the potential to foster European identity, ${ }^{4}$

2 Kuhn, T., H. Solaz \& E. Van Elsas (2017), 'Practising what you preach: How cosmopolitanism promotes willingness to redistribute across the European Union', Journal of European Public Policy online first, https://doi.org/10.1080 /13501763.2017.1370005; Bechtel, M., J. Hainmueller \& Y. Margalit (2014), 'Preferences for International Redistribution. The Divide over the Eurozone Bailouts', American Journal of Political Science 58 (4): 835-856.

3 European Commission (2016), European Voluntary Service 20 Years!, available at http://europa.eu/youth/sites/default/files/evs_factsheet_and_impacts apr_2016.pdf

4 Mitchell. K. (2015) 'Rethinking the "Erasmus effect" on European identity', JCMS: Journal of Common Market Studies 53 (2): 330-348. 
students who take part in such an exchange are already more pro-European than their peers before going abroad. ${ }^{5}$ Moreover they primarily interact with other Erasmus students rather than the (immobile) local students. Such a self-selection might contribute to the widening gulf between Eurosceptics and Europhiles: People open to European integration self-select into participating in European voluntary services and into paying voluntary contributions. By doing so, they strengthen and reaffirm their pre-existing support for European integration, and are increasingly surrounded by like-minded, equally mobile individuals, while Eurosceptics remain in their own country and in their own Eurosceptic circles.

To sum up the argument so far, all these proposals primarily address those Europeans who are already European-minded and self-select into transnational interactions and European engagement. I suggest addressing the Eurosceptics, but in a somewhat different way than Ferrera. He proposes to compensate the stayers by means of an EU fund to ease the impact of mobility. Joppke has already pointed out that by doing so, European policy makers might reify and legitimise populist resentments by portraying movers as perpetrators and stayers as victims. One way to deal with this concern could be to frame these transfers differently. For example, rather than speaking of a 'compensation for losers', one could offer a 'mobility bonus' to those regions (and their residents) that are able to attract large shares of EU migrant workers. These bonuses could be earmarked for investments into activating unemployed residents. Consequently, those Europeans who usually tend to see themselves as losers of European integration might feel that they benefit from being part of a winning region. My other concern about such a 'compensation' policy is that it might 'nudge' stayers into the wrong direction. If intra-European mobility indeed fosters European identity, and pro-European citizens self-select into mobility, then we should provide incentives for stayers to overcome their reservations and move around rather than giving them a premium for staying at home. This is a very difficult endeavour, and the Erasmus Plus Programme already tries to reach out to a broader cross section of society beyond university students.

Finally, given the widening gap between mobile and immobile Europeans, the answer to Euroscepticism might not lie in promoting more mobility across European member states but in addressing the increasing socioeconomic divides and opening up the resulting 'echo chambers' within

5 Wilson, I. (2011), 'What Should We Expect of "Erasmus Generations"?', Journal of Common Market Studies 49 (5): 1113-1140. 
countries. By trying to engage in a dialogue with Eurosceptic co-nationals, Europhiles might be able find to better answers than by repeating the Europhile mantra.

Open Access This chapter is licensed under the terms of the Creative Commons Attribution 4.0 International License (http://creativecommons.org/licenses/by/4.0/), which permits use, sharing, adaptation, distribution and reproduction in any medium or format, as long as you give appropriate credit to the original author(s) and the source, provide a link to the Creative Commons license and indicate if changes were made.

The images or other third party material in this chapter are included in the chapter's Creative Commons license, unless indicated otherwise in a credit line to the material. If material is not included in the chapter's Creative Commons license and your intended use is not permitted by statutory regulation or exceeds the permitted use, you will need to obtain permission directly from the copyright holder. 